\title{
Clinical verification of the relationship between smoking and the immune microenvironment of breast cancer
}

\author{
Koji Takada', Shinichiro Kashiwagi ${ }^{1,4^{*}} \mathbb{D}$, Yuka Asano ${ }^{1}$, Wataru Goto ${ }^{1}$, Katsuyuki Takahashi ${ }^{2}$, Hisakazu Fujita ${ }^{3}$, \\ Tsutomu Takashima', Shuhei Tomita², Kosei Hirakawa' and Masaichi Ohira'
}

\begin{abstract}
Background: The immune tumor microenvironment (iTME) is thought to affect the response to chemotherapy, and tumor-infiltrating lymphocytes (TILs) are often used as an indicator to evaluate the iTME. Smoking is involved in carcinogenesis, the relationship between smoking and the iTME of lung cancer has been reported. We hypothesized that smoking would affect the iTME of breast cancer and aimed to examine this relationship based on the amount of pre-diagnosis smoking and the subsequent effects on treatment response and prognosis.
\end{abstract}

Methods: This retrospective study evaluated data from 149 patients who underwent preoperative chemotherapy for triple-negative or HER2-enriched breast cancer. TILs were assessed in biopsy specimens at diagnosis. The data of all patients were used to calculate each patient's smoking amount based on pack-years.

Results: Relative to the low smoking group, the high smoking group had a significant greater TILs density $(p=0.043)$ and a significantly better pathological complete response $(p C R)$ rate $(p=0.042)$. However, there was no significant difference according to smoking amount in disease-free survival $(p=0.114)$ or overall survival $(p=0.347)$.

Conclusions: Smoking may influence the iTME, with an activated iTME being associated with pCR rate. Therefore, controlled activation of the microenvironment in this setting may help improve patients' prognosis.

Keywords: Breast cancer, Smoking, Tumor-infiltrating lymphocytes, Tumor microenvironment, Immune response, Brinkman index

\section{Background}

The immune tumor microenvironment (iTME) is thought to affect the response to chemotherapy, and tumor-infiltrating lymphocytes (TILs) are often used as an indicator to evaluate the iTME [1-3]. Many studies have revealed that a high TILs density in breast cancer is associated with good therapeutic effects, such as pathological complete response (pCR), prolonged disease-free survival (DFS), and prolonged overall survival (OS) $[4,5]$. It became commonly known that affect TILs density in breast cancer is the cancer subtype, with many reports

\footnotetext{
*Correspondence: spqv9ke9@view.ocn.ne.jp

${ }^{4}$ Department of Surgical Oncology, Osaka City University Graduate

School of Medicine, 1-4-3 Asahi-machi, Abeno-ku, Osaka 545-8585, Japan
}

Full list of author information is available at the end of the article indicating that a high TILs density is associated with high-risk subtypes, such as triple-negative breast cancer (TNBC) and human epidermal growth factor receptor 2-enriched breast cancer (HER2BC) [6, 7]. In recent years, it has also been reported that special genes affect TILs, and it is also important to examine the relationship between genes and the iTME $[8,9]$.

Smoking is involved in the genesis of many carcinomas, including breast cancer [8], with the carcinogenic substances in tobacco smoke causing chronic inflammatory conditions in the microvessels $[10,11]$. Recent studies have also indicated that the iTME is deeply involved in carcinogenesis and that chronic inflammation promotes this process $[12,13]$. The relationship between smoking and the iTME of lung cancer has been reported [5, 14], although no reports have examined the relationship 
between smoking and the iTME of breast cancer. Therefore, we hypothesized that smoking would affect the iTME of breast cancer and aimed to examine this relationship based on the amount of pre-diagnosis smoking and the subsequent effects on treatment response and prognosis.

\section{Methods}

\section{Patient background}

This retrospective study evaluated data from 149 patients who underwent preoperative chemotherapy (POC) for resectable TNBC or HER2BC between February 2007 and December 2017 at the Osaka City University Hospital. All patients were questioned regarding their smoking history at the initial visit (cigarettes smoked per day and years of smoking), and the data were used to calculate each patient's smoking amount based on pack-years (Table 1). The breast cancers were diagnosed pathologically and classified according to subtype based on the immunohistochemical expression of estrogen receptor (ER), progesterone receptor (PgR), human epidermal growth factor receptor 2 (HER2), and K-i67. Cases were defined as either HER2BC (ER-, PgR-, and HER2+) or TNBC (ER-, PgR-, and HER2-).

All patients received a standardized outpatient POC regimen that consisted of four courses of FEC100 (fluorouracil: $500 \mathrm{mg} / \mathrm{m}^{2}$, epirubicin: $100 \mathrm{mg} / \mathrm{m}^{2}$, and cyclophosphamide: $500 \mathrm{mg} / \mathrm{m}^{2}$ ) every 3 weeks, which was followed by 12 courses of weekly paclitaxel $\left(80 \mathrm{mg} / \mathrm{m}^{2}\right)$. The patients with HER2BC also received trastuzumab during the paclitaxel treatment as a weekly dose $(2 \mathrm{mg} /$ $\mathrm{kg})$ or tri-weekly dose $(6 \mathrm{mg} / \mathrm{kg})$ [15-17]. Staging and therapeutic effect were evaluated using ultrasonography, computed tomography, and bone scintigraphy based on the Response Evaluation Criteria in Solid Tumors [18]. Patients who achieved clinically partial or complete response were categorized as "responders" in the objective response rate (ORR), while patients with clinically stable or progressive disease were defined as "non-responders". The patients subsequently underwent mastectomy or breast-conserving surgery [19], and the pathological therapeutic effect of the POC was evaluated using the resected specimens. Pathological complete

\section{Table 1 Pack-years of smoking}

\footnotetext{
To calculate smoking pack-years:

Divide the number of cigarettes smoked per day by 20 (the number of cigarettes in a pack)

Then multiply by the number of years smoked

ex. 1 (70 cigarettes $/$ day $\div 20$ cigarettes $/$ pack $) \times 10$ years $=35$ pack-years

ex. 2 (35 cigarettes $/$ day $\div 20$ cigarettes $/$ pack $) \times 20$ years $=35$ pack-years

ex. 3 (20 cigarettes $/$ day $\div 20$ cigarettes $/$ pack $) \times 20$ years $=20$ pack-years
}

response (pCR) was defined as complete disappearance of the lesion's invasive components, including the lymph nodes, with or without intraductal components, according to the National Surgical Adjuvant Breast and Bowel Project B-18 protocol [20]. All patients received postoperative radiotherapy delivered to the remnant breast, and the standard postoperative adjuvant therapy was selected based on the cancer subtype. Patients were followed-up after surgery to detect recurrence using physical examinations every 3 months, ultrasonography every 6 months, and computed tomography and bone scintigraphy annually. The DFS interval was calculated from the day of surgery to the first instance of recurrence or death, while OS was calculated from the day of surgery to death.

\section{Histopathological evaluation of TILs density}

Specimens that were used to pathologically diagnose breast cancer (obtained via core needle biopsy or vacuum-assisted biopsy) were used to determine the TILs density. In the present study, TILs were defined as lymphocytes infiltrating within the tumor stroma [21]. The TILs density was calculated as the average from five randomly selected fields, and the results were classified as a score of $3(>50 \%)$, a score of $2(11-50 \%)$, a score of $1(\leq 10 \%)$, or a score of 0 (absent) (Additional file 1: Fig. S1). Based on previous reports [22, 23], we defined a high TILs density as scores of $2-3$ (i.e., $>10 \%$ ) and a low TILs density as scores of $0-1(\leq 10 \%)$.

\section{Statistical analysis}

All analyses were performed using JMP software (version 11; SAS Institute, Cary, NC). Differences in the study variables were evaluated using the Chi square test or Fisher's exact test, as appropriate. The Kaplan-Meier method was used to estimate the DFS and OS outcomes, which were compared using the log-rank test. A Cox proportional hazards model was used to calculate hazard ratios (HRs) and 95\% confidence intervals (CIs), and multivariable analysis was performed using a Cox regression model and the backward stepwise selection method. Differences were considered statistically significant at $\mathrm{p}$-values of $<0.05$.

\section{Ethics statement}

This study was conducted at the Osaka City University Graduate School of Medicine (Osaka, Japan) according to the Reporting Recommendations for Tumor Marker Prognostic Studies (REMARK) guidelines. The study protocol involved a retrospectively written research, pathological evaluation, and statistical analysis plan [24]. The study complied with the provisions of the Declaration of 
Table 2 Clinicopathological features of 149 patients who were treated with preoperative chemotherapy

\begin{tabular}{ll}
\hline Parameters ( $\boldsymbol{n}=149)$ & Number of patients (\%) \\
\hline Age (years old) & $56(24-75)$ \\
Tumour size (mm) & $27.6(10.2-98.0)$ \\
Skin infiltration & \\
Negative/positive & $134(89.9 \%) / 15(10.1 \%)$ \\
Lymph node metastasis & \\
No/N1/N2/N3 & $51(34.2 \%) / 54(36.2 \%) / 29$ \\
HER2 & $(19.5 \%) / 15(10.1 \%)$ \\
Negative/positive & $87(58.4 \%) / 62(41.6 \%)$ \\
Ki67 & $23(15.4 \%) / 126(84.6 \%)$ \\
Negative/positive & $11(7.4 \%) / 138(92.6 \%)$ \\
ORR & \\
Non-responders/responders & $75(50.3 \%) / 74(49.7 \%)$ \\
pCR & $123(82.6 \%) / 26(17.4 \%)$ \\
Negative/positive & \\
Recurrence & $58(38.9 \%) / 91(61.1 \%)$ \\
Negative/positive & $105(70.5 \%) / 44(29.5 \%)$ \\
TILs & $20(2.5-135)$ \\
Low/high & \\
Smoker & $106(71.1 \%) / 43(28.9 \%)$ \\
No/yes & \\
Pack-years of smokers & \\
Pack-years & \\
Low/high &
\end{tabular}

HER human epidermal growth factor receptor, $O R R$ objective response rate, $p C R$ pathological complete response, TILs tumour-infiltrating lymphocytes

Helsinki, and all patients provided written informed consent for their treatment and data collection. The study's retrospective protocol was approved by the ethics committee of Osaka City University (\#926).

\section{Results}

\section{Clinicopathological features}

The clinicopathological features of the 149 women are listed in Table 2 . The median age at surgery was 56 years (range 24-75 years old). The median follow-up duration was 1288 days after surgery (range 13-3615 days). The median tumor diameter was $27.6 \mathrm{~mm}$ (range 10.2$98.0 \mathrm{~mm}$ ) and 98 patients $(65.8 \%)$ were diagnosed with N1-3 lymph node metastasis based on their imaging results. Sixty-two patients had HER2BC (41.6\%) and 87 patients had TNBC (58.4\%). Ninety-one patients (61.1\%) had a high TILs density and 58 patients (38.9\%) had a low TILs density at their diagnosis. One hundred and five patients $(70.5 \%)$ reported never smoking, and 44 patients (29.5\%) reported a median smoking amount of 20 packyears (range 2.5-135 pack-years). Based on the receiver
Table 3 Comparison of clinicopathological features by subtype

\begin{tabular}{|c|c|c|c|}
\hline \multirow[t]{2}{*}{ Parameters } & \multicolumn{2}{|l|}{ Intrinsic subtype } & \multirow[t]{2}{*}{$p$ value } \\
\hline & $\begin{array}{l}\text { HER2-enriched } \\
\text { breast cancer } \\
(n=62)\end{array}$ & $\begin{array}{l}\text { Triple-negative } \\
\text { breast cancer } \\
(n=87)\end{array}$ & \\
\hline \multicolumn{4}{|l|}{ Age (years old) } \\
\hline$\leq 56$ & $26(41.9 \%)$ & $49(56.3 \%)$ & \multirow[t]{2}{*}{0.085} \\
\hline$>56$ & $36(58.1 \%)$ & 38 (43.7\%) & \\
\hline \multicolumn{4}{|l|}{ Tumour size (mm) } \\
\hline$\leq 27.6$ & $30(48.4 \%)$ & 45 (51.7\%) & \multirow[t]{2}{*}{0.690} \\
\hline$>27.6$ & $32(51.6 \%)$ & $42(48.3 \%)$ & \\
\hline \multicolumn{4}{|l|}{ Skin infiltration } \\
\hline Negative & $54(87.1 \%)$ & 80 (92.0\%) & \multirow[t]{2}{*}{0.335} \\
\hline Positive & $8(12.9 \%)$ & 7 (8.0\%) & \\
\hline \multicolumn{4}{|l|}{ Lymph node status } \\
\hline Negative & $25(40.3 \%)$ & $26(29.9 \%)$ & \multirow[t]{2}{*}{0.188} \\
\hline Positive & $37(59.7 \%)$ & $61(70.1 \%)$ & \\
\hline \multicolumn{4}{|l|}{ Ki67 } \\
\hline Negative & $14(22.6 \%)$ & $9(10.3 \%)$ & \multirow[t]{2}{*}{0.042} \\
\hline Positive & $48(77.4 \%)$ & 78 (89.7\%) & \\
\hline \multicolumn{4}{|l|}{ ORR } \\
\hline Non-responders & $1(1.6 \%)$ & $10(11.5 \%)$ & \multirow[t]{2}{*}{0.023} \\
\hline Responders & $61(98.4 \%)$ & 77 (88.5\%) & \\
\hline \multicolumn{4}{|l|}{$\mathrm{pCR}$} \\
\hline Negative & $26(41.9 \%)$ & $49(56.3 \%)$ & \multirow[t]{2}{*}{0.085} \\
\hline Positive & $36(58.1 \%)$ & $38(43.7 \%)$ & \\
\hline \multicolumn{4}{|l|}{ Recurrence } \\
\hline Negative & 55 (88.7\%) & 68 (78.2\%) & \multirow[t]{2}{*}{0.096} \\
\hline Positive & $7(11.3 \%)$ & $19(21.8 \%)$ & \\
\hline \multicolumn{4}{|l|}{ TILS } \\
\hline Low & $20(32.3 \%)$ & $38(43.7 \%)$ & \multirow[t]{2}{*}{0.206} \\
\hline High & $42(67.7 \%)$ & $49(56.3 \%)$ & \\
\hline \multicolumn{4}{|l|}{ Pack-years } \\
\hline Low & $40(64.5 \%)$ & $66(75.9 \%)$ & \multirow[t]{2}{*}{0.134} \\
\hline High & $22(35.5 \%)$ & $21(24.1 \%)$ & \\
\hline
\end{tabular}

HER human epidermal growth factor receptor, $O R R$ objective response rate, $p C R$ pathological complete response, TILs tumour-infiltrating lymphocytes

operating characteristic curve analysis, the optimal smoking cut-off value for predicting DFS was defined as 2.5 pack-years, which yielded a distribution of 43 patients (28.9\%) in the high smoking group and 106 patients $(71.1 \%)$ in the low-smoking group (area under the curve: 0.588 , sensitivity: 0.325 , specificity: 0.846 ) (Additional file 2: Fig. S2). The ORR was $82.6 \%$ and 74 patients (49.7\%) achieved a pCR. The therapeutic response was significantly higher among patients with HER2BC than among patients with TNBC $(\mathrm{p}=0.023)$ (Table 3). However, there were no significant differences in the two 
Table 4 Difference in clinicopathological features due to pack-years

\begin{tabular}{|c|c|c|c|c|c|c|}
\hline \multirow[t]{2}{*}{ Parameters } & \multicolumn{2}{|l|}{ Smoker } & \multirow[t]{2}{*}{$p$ value } & \multicolumn{2}{|l|}{ Pack-years } & \multirow[t]{2}{*}{$p$ value } \\
\hline & Yes $(n=44)$ & No $(n=105)$ & & High $(n=43)$ & Low $(n=106)$ & \\
\hline \multicolumn{7}{|l|}{ Age (years old) } \\
\hline$\leq 56$ & $24(54.5 \%)$ & $51(48.6 \%)$ & 0.509 & $24(55.8 \%)$ & $51(48.1 \%)$ & 0.398 \\
\hline$>56$ & $20(45.5 \%)$ & $54(51.4 \%)$ & & $19(44.2 \%)$ & $55(51.9 \%)$ & \\
\hline \multicolumn{7}{|l|}{ Tumour size (mm) } \\
\hline$\leq 27.6$ & $25(56.8 \%)$ & $50(47.6 \%)$ & 0.309 & $25(58.1 \%)$ & $50(47.2 \%)$ & 0.228 \\
\hline$>27.6$ & 19 (43.2\%) & $55(52.4 \%)$ & & $18(41.9 \%)$ & $56(52.8 \%)$ & \\
\hline \multicolumn{7}{|l|}{ Skin infiltration } \\
\hline Negative & 40 (90.9\%) & 94 (89.5\%) & 0.799 & 40 (93.0\%) & $94(88.7 \%)$ & 0.428 \\
\hline Positive & $4(9.1 \%)$ & $11(10.5 \%)$ & & $3(7.0 \%)$ & $12(11.3 \%)$ & \\
\hline \multicolumn{7}{|l|}{ Lymph node status } \\
\hline Negative & $18(40.9 \%)$ & $33(31.4 \%)$ & 0.269 & $18(41.9 \%)$ & $33(31.1 \%)$ & 0.214 \\
\hline Positive & $26(59.1 \%)$ & $72(68.6 \%)$ & & $25(58.1 \%)$ & 73 (68.9\%) & \\
\hline \multicolumn{7}{|l|}{ Ki67 } \\
\hline Negative & $6(13.6 \%)$ & $17(16.2 \%)$ & 0.69 & $6(14.0 \%)$ & $17(16.0 \%)$ & 0.752 \\
\hline Positive & 38 (86.4\%) & $88(83.8 \%)$ & & 37 (86.0\%) & 89 (84.0\%) & \\
\hline \multicolumn{7}{|l|}{ Intrinsic subtype } \\
\hline HER2-enriched & $22(50.0 \%)$ & $40(38.1 \%)$ & 0.181 & $22(51.2 \%)$ & $40(37.7 \%)$ & 0.134 \\
\hline Triple-negative & $22(50.0 \%)$ & 65 (61.9\%) & & $21(48.8 \%)$ & $66(62.3 \%)$ & \\
\hline \multicolumn{7}{|l|}{ ORR } \\
\hline Non-responders & $3(6.8 \%)$ & $8(7.6 \%)$ & 0.866 & $3(7.0 \%)$ & $8(7.5 \%)$ & 0.905 \\
\hline Responders & 41 (93.2\%) & 97 (92.4\%) & & 40 (93.0\%) & $98(92.5 \%)$ & \\
\hline \multicolumn{7}{|l|}{$\mathrm{pCR}$} \\
\hline Negative & 17 (38.6\%) & $58(55.2 \%)$ & 0.065 & $16(37.2 \%)$ & $59(55.7 \%)$ & 0.042 \\
\hline Positive & 27 (61.4\%) & 47 (44.8\%) & & 27 (62.8\%) & 47 (44.3\%) & \\
\hline \multicolumn{7}{|l|}{ Recurrence } \\
\hline Negative & 40 (90.9\%) & 83 (79.0\%) & 0.083 & 39 (90.7\%) & 84 (79.2\%) & 0.096 \\
\hline Positive & 4 (9.1\%) & 22 (21.0\%) & & 4 (9.3\%) & 22 (20.8\%) & \\
\hline \multicolumn{7}{|l|}{ TILS } \\
\hline Low & 13 (29.6\%) & 45 (42.9\%) & 0.075 & 12 (27.9\%) & $46(43.4 \%)$ & 0.043 \\
\hline High & 31 (70.5\%) & 60 (57.1\%) & & 31 (72.1\%) & 60 (56.6\%) & \\
\hline
\end{tabular}

HER human epidermal growth factor receptor, ORR objective response rate, $p C R$ pathological complete response, TILs tumour-infiltrating lymphocytes

groups' $\mathrm{pCR}$ rates $(\mathrm{p}=0.085)$, TILs density $(\mathrm{p}=0.206)$, or smoking amount $(\mathrm{p}=0.134)$.

\section{The associations of smoking with clinicopathological features, DFS, and OS}

Table 4 shows the results of the associations between smoking and the patients' clinicopathological features. No significant correlation was found between comparing smokers and never smokers. However, when divided into two groups according to smoking amount, correlation with clinicopathological features was recognized. Relative to the low smoking group, the high smoking group had a significant greater TILs density $(p=0.043)$ and a significantly better $\mathrm{pCR}$ rate $(\mathrm{p}=0.042)$. In the univariate analysis, prolonged DFS was significantly associated with
pCR ( $<<0.001$, HR 0.203, 95\% CI 0.068-0.499) and a high TILs density ( $\mathrm{p}=0.001$, HR 0.252 , 95\% CI $0.107-0.553$ ) (Table 5). In addition, prolonged OS was significantly associated with $\mathrm{pCR}(\mathrm{p}=0.002$, HR 0.183 , 95\% CI $0.042-$ $0.561)$ and a high TILs density $(\mathrm{p}=0.035$, HR $0.357,95 \%$ CI 00.129-0.929) (Table 5). However, there was no significant difference according to smoking amount in DFS $(\mathrm{p}=0.114)$ or $\mathrm{OS}(\mathrm{p}=0.347)($ Fig. 1$)$.

\section{Discussion}

Smoking is a risk factor for various carcinomas, including breast cancer [25]. Smoking-related carcinogenesis is linked to various factors, with some of the components in tobacco smoke having estrogenic effects and others having antiestrogenic effects [26, 27]. Moreover, tobacco 
Table 5 Univariate and multivariate analysis with respect to disease-free survival and overall survival

\begin{tabular}{|c|c|c|c|c|c|c|}
\hline \multirow[t]{2}{*}{ Parameters } & \multicolumn{3}{|c|}{ Univariate analysis } & \multicolumn{3}{|c|}{ Multivariate analysis } \\
\hline & Hazard ratio & $95 \% \mathrm{Cl}$ & $p$ value & Hazard ratio & $95 \% \mathrm{Cl}$ & $p$ value \\
\hline \multicolumn{7}{|l|}{ Disease-free survival } \\
\hline \multicolumn{7}{|c|}{ Age at operation (year) } \\
\hline$\leq 56$ & 0.614 & $0.269-1.335$ & 0.220 & & & \\
\hline \multicolumn{7}{|l|}{$>56$} \\
\hline \multicolumn{7}{|l|}{ Tumour size (mm) } \\
\hline$\leq 27.6$ & 1.137 & $0.525-2.503$ & 0.744 & & & \\
\hline \multicolumn{7}{|l|}{$>27.6$} \\
\hline \multicolumn{7}{|l|}{ Skin infiltration } \\
\hline Negative & 1.556 & $0.455-4.067$ & 0.440 & & & \\
\hline \multicolumn{7}{|l|}{ Positive } \\
\hline \multicolumn{7}{|l|}{ Lymph node status } \\
\hline Negative & 2.440 & $0.933-8.343$ & 0.071 & 1.677 & $0.617-5.859$ & 0.331 \\
\hline \multicolumn{7}{|l|}{ Positive } \\
\hline \multicolumn{7}{|l|}{ Ki67 } \\
\hline Negative & 0.394 & $0.180-0.926$ & 0.034 & 0.770 & $0.321-1.942$ & 0.568 \\
\hline \multicolumn{7}{|l|}{ Positive } \\
\hline \multicolumn{7}{|l|}{ Intrinsic subtype } \\
\hline HER2-enriched & 1.884 & $0.828-4.823$ & 0.135 & & & \\
\hline \multicolumn{7}{|l|}{ Triple-negative } \\
\hline \multicolumn{7}{|l|}{ ORR } \\
\hline Non-responders & 0.083 & $0.035-0.210$ & $<0.001$ & 0.154 & $0.059-0.426$ & 0.001 \\
\hline \multicolumn{7}{|l|}{ Responders } \\
\hline \multicolumn{7}{|c|}{ Pathological response } \\
\hline Non-pCR & 0.203 & $0.068-0.499$ & $<0.001$ & 0.381 & $0.118-1.059$ & 0.065 \\
\hline \multicolumn{7}{|l|}{$\mathrm{pCR}$} \\
\hline \multicolumn{7}{|l|}{ TILs } \\
\hline Low & 0.252 & $0.107-0.553$ & 0.001 & 0.424 & $0.167-1.032$ & 0.059 \\
\hline High & & & & & & \\
\hline Pack-years & & & & & & \\
\hline Low & 0.434 & $0.127-1.134$ & 0.092 & 0.567 & $0.160-1.555$ & 0.289 \\
\hline High & & & & & & \\
\hline Overall survival & & & & & & \\
\hline Age at operation (y & & & & & & \\
\hline$\leq 56$ & 0.508 & $0.175-1.338$ & 0.172 & & & \\
\hline$>56$ & & & & & & \\
\hline Tumour size (mm) & & & & & & \\
\hline$\leq 27.6$ & 1.123 & $0.429-2.993$ & 0.811 & & & \\
\hline$>27.6$ & & & & & & \\
\hline Skin infiltration & & & & & & \\
\hline Negative & 1.939 & $0.446-5.977$ & 0.335 & & & \\
\hline Positive & & & & & & \\
\hline Lymph node status & & & & & & \\
\hline Negative & 2.778 & $0.781-17.657$ & 0.125 & & & \\
\hline Positive & & & & & & \\
\hline Ki67 & & & & & & \\
\hline Negative & 0.638 & $0.234-2.023$ & 0.419 & & & \\
\hline Positive & & & & & & \\
\hline
\end{tabular}


Table 5 (continued)

\begin{tabular}{|c|c|c|c|c|c|c|}
\hline \multirow[t]{2}{*}{ Parameters } & \multicolumn{3}{|c|}{ Univariate analysis } & \multicolumn{3}{|c|}{ Multivariate analysis } \\
\hline & Hazard ratio & $95 \% \mathrm{Cl}$ & $p$ value & Hazard ratio & $95 \% \mathrm{Cl}$ & $p$ value \\
\hline \multicolumn{7}{|l|}{ Intrinsic subtype } \\
\hline $\begin{array}{l}\text { HER2-enriched } \\
\text { Triple-negative }\end{array}$ & 1.610 & $0.597-5.060$ & 0.357 & & & \\
\hline \multicolumn{7}{|l|}{ ORR } \\
\hline $\begin{array}{l}\text { Non-responders } \\
\text { Responders }\end{array}$ & 0.077 & $0.026-0.238$ & $<0.001$ & 0.451 & $0.044-0.520$ & 0.004 \\
\hline \multicolumn{7}{|c|}{ Pathological response } \\
\hline $\begin{array}{l}\text { Non-pCR } \\
p C R\end{array}$ & 0.183 & $0.042-0.561$ & 0.002 & 0.282 & $0.062-0.953$ & 0.041 \\
\hline \multicolumn{7}{|l|}{ TILS } \\
\hline $\begin{array}{l}\text { Low } \\
\text { High }\end{array}$ & 0.357 & $0.129-0.929$ & 0.035 & 0.634 & $0.212-1.861$ & 0.403 \\
\hline \multicolumn{7}{|l|}{ Pack-years } \\
\hline $\begin{array}{l}\text { Low } \\
\text { High }\end{array}$ & 0.554 & $0.128-1.700$ & 0.325 & & & \\
\hline
\end{tabular}

OS overall survival, $C I$ confidence intervals, $H E R$ human epidermal growth factor receptor, ORR objective response rate, $p C R$ pathological complete response, $T I L s$ tumour-infiltrating lymphocytes

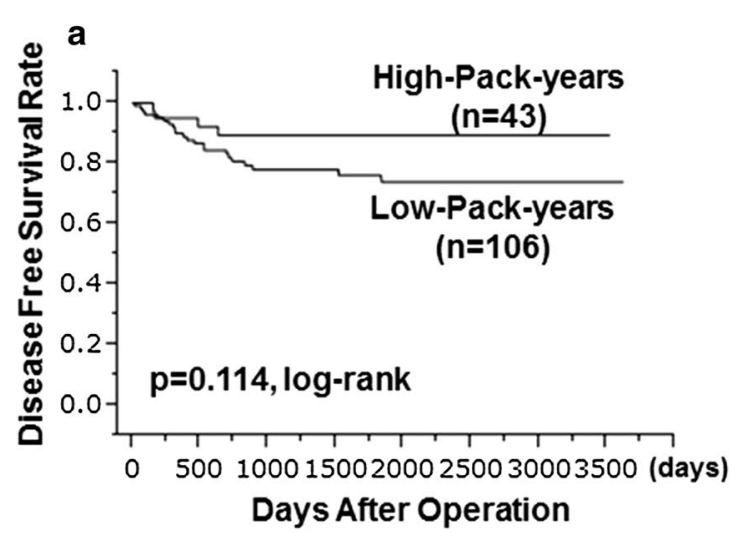

Fig. 1 A comparison of disease-free survival (DFS) and overall survival (OS) between the groups with high and low smoking levels failed to detect significant differences in DFS (a) or OS (b) components can be carried through the blood to the mammary gland tissues where they cause DNA damage $[10,11]$. Some researchers have indicated that smoking is associated with the development of ER+ breast cancer, while many others have reported that smoking is associated with ER- breast cancer [26-31]. These differences may be related to race [27], which would be consistent with our findings, as all of our patients were Japanese and had ER - cancers. Furthermore, tissue culture and animal experiments have indicated that tobacco smoke components increase proliferative capacity and cause malignant transformation [32-34], which further highlights the

\section{b}

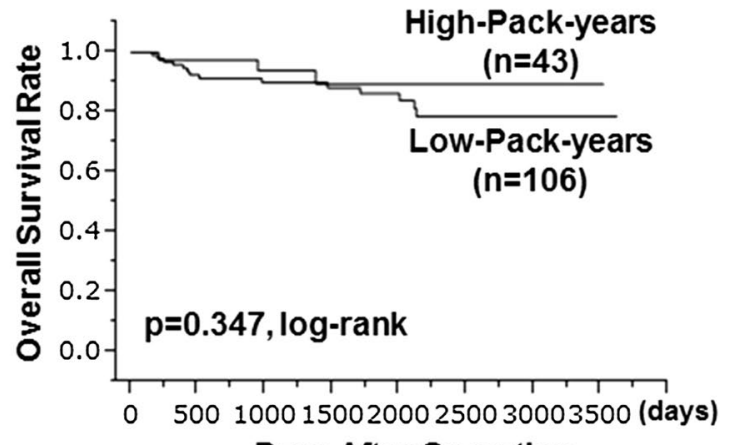

Days After Operation relationship between smoking and the development of TNBC or HER2BC.

The present study indicated that the HER2BC and TNBC subtypes were related to smoking and the cancer's pre-treatment iTME. Interestingly, previous reports have indicated that a high TILs density was significantly associated with prolonged DFS and OS $[4,5]$, and the present study indicated that TILs density was associated with the pre-diagnosis smoking amount. These results indicate that local microimmune reactions are activated by chronic inflammation in microvessels, which may be related to the release of 
antigens as a result of smoking-related DNA damage. Given that a higher smoking amount was associated with a high TILs density, it is possible that smoking was related to the high $\mathrm{pCR}$ rate.

Although no previous studies have evaluated the relationship between smoking and the iTME in breast cancer, that relationship has been studied in lung cancer. For example, in non-small cell lung cancer, smoking was not associated with the expression of $\mathrm{CD} 3, \mathrm{CD} 4$, forkhead box protein 3 (FOXP3), and CD20, although smoking was associated with increased CD8 expression $[14,35]$. Furthermore, increased numbers of CD8+ T-cells is associated with a good prognosis among patients with non-small cell lung cancer $[14,36]$. Moreover, CD8 is a marker for cytotoxic T-cells, which are associated with an improved prognosis among patients with breast cancer [2,37]. Although the present study did not directly evaluate the correlation between smoking and DFS or OS, the overall exposure to tobacco smoke is known to be associated with the risks of breast cancer recurrence, breast cancer-related death, and overall mortality $[38,39]$. In this context, smoking could activate the iTME and affect the short-term therapeutic effect (i.e., pCR rate), although it might not be associated with the long-term therapeutic effect (i.e., DFS or OS) because it is not correlated with low oxygen levels caused by microangiopathy or deterioration of the iTME.

The present study has several limitations. First, the smoking amount was retrospective determined using self-reported data from at the patient's diagnosis. Second, we did not consider smoking status after diagnosis or second-hand smoke, although passive smoking is an important risk factor for carcinogenesis [25] and lifelong exposure to smoke is more strongly related to the risks of carcinogenesis and recurrence (vs. current smoking status) $[38,39]$. It is also reported that special genes, such as MAPKs/TP53, are affecting the iTME $[8,9]$. That is, the iTME is also strongly related to genes. Since this result has only been investigated retrospectively, it is necessary to further examine the relationship between smoking and iTME with such as immunohistochemical staining, gene analysis or experiments in vitro. Moreover, it will be important to consider complete smoking-related data to examine the association of smoking with long-term prognosis among patients with breast cancer.

\section{Conclusions}

In conclusion, smoking may influence the iTME, with an activated iTME being associated with PCR rate. Therefore, controlled activation of the microenvironment in this setting may help improve patients' prognosis.

\section{Additional files}

Additional file 1: Fig. S1. Histopathological evaluation of tumor-infiltrating lymphocytes (TILs) density. Specimens were obtained to pathologically diagnose breast cancer using core needle biopsy or vacuum-assisted biopsy, and these specimens were evaluated to calculate the TILs density, which was calculated as the average for five randomly selected stromal regions with lymphoplasmacytic infiltration. (A) $>50 \%$, score 3. (B) 11-50\%, score 2. (C) $\leq 10 \%$, score 1. (D) Absent, score 0 .

Additional file 2: Fig. S2. Receiver operating characteristic curve analysis. The optimal cut-off value for using smoking to predict disease-free survival was identified as 50 pack-years (area under the curve: 0.588, sensitivity $=0.325$, specificity $=0.846$ )

\section{Abbreviations}

ITME: immune tumor microenvironment; TILs: tumor-infiltrating lymphocytes; pCR: pathological complete response; DFS: disease-free survival; OS: overall survival; TNBC: triple-negative breast cancer; HER2BC: human epidermal growth factor receptor 2-enriched breast cancer; POC: preoperative chemotherapy; ER: estrogen receptor; PgR: progesterone receptor; HER2: human epidermal growth factor receptor 2; ORR: objective response rate; $\mathrm{pCR}$ : pathological complete response; HR: hazard ratio; Cl: confidence interval; REMARK: Reporting Recommendations for Tumor Marker Prognostic Studies; FOXP3: forkhead box protein 3.

\section{Authors' contributions}

All authors were involved in the preparation of this manuscript. KTakada collected the data, and wrote the manuscript. SK, YA, WG, KTakahashi and TT performed the operation and designed the study. KTakada, SK and ST summarized the data and revised the manuscript. HF, KH and MO substantial contribution to the study design, performed the operation, and revised the manuscript. All authors read and approved the final manuscript.

\section{Author details}

${ }^{1}$ Department of Breast and Endocrine Surgery, Osaka City University Graduate School of Medicine, 1-4-3 Asahi-machi, Abeno-ku, Osaka 545-8585, Japan. ${ }^{2}$ Department of Pharmacology, Osaka City University Graduate School of Medicine, 1-4-3 Asahi-machi, Abeno-ku, Osaka 545-8585, Japan. ${ }^{3}$ Department of Scientific and Linguistic Fundamentals of Nursing, Osaka City University Graduate School of Nursing, 1-5-17 Asahi-machi, Abeno-ku, Osaka 545-0051, Japan. ${ }^{4}$ Department of Surgical Oncology, Osaka City University Graduate School of Medicine, 1-4-3 Asahi-machi, Abeno-ku, Osaka 545-8585, Japan.

\section{Acknowledgements}

We thank Yayoi Matsukiyo and Tomomi Okawa (Department of Surgical Oncology, Osaka City University Graduate School of Medicine) for helpful advice regarding data management.

\section{Competing interests}

The authors declare that they have no competing interests.

\section{Availability of data and materials}

The datasets supporting the conclusions of this article is included within the article.

\section{Consent for publication}

Not applicable.

\section{Ethics approval and consent to participate}

Written informed consent was obtained from all subjects. This research conformed to the provisions of the Declaration of Helsinki in 2013. All patients were informed of the investigational nature of this study and provided their written, informed consent. The study protocol was approved by the Ethics Committee of Osaka City University (\#926). 


\section{Funding}

This study was supported in part by Grants-in Aid for Scientific Research (KAKENHI, Nos. 25461992, 26461957, and 17K10559) from the Ministry of Education, Science, Sports, Culture and Technology of Japan.

\section{Publisher's Note}

Springer Nature remains neutral with regard to jurisdictional claims in published maps and institutional affiliations.

Received: 28 September 2018 Accepted: 2 January 2019

Published online: 07 January 2019

\section{References}

1. Zitvogel L, Kepp O, Kroemer G. Immune parameters affecting the efficacy of chemotherapeutic regimens. Nat Rev Clin Oncol. 2011;8(3):151-60.

2. Fridman WH, Pages F, Sautes-Fridman C, Galon J. The immune contexture in human tumors: impact on clinical outcome. Nat Rev Cancer. 2012;12(4):298-306

3. Couzin-Frankel J. Breakthrough of the year 2013. Cancer immunotherapy. Science. 2013:342(6165):1432-3.

4. Adams S, Gray RJ, Demaria S, Goldstein L, Perez EA, Shulman LN, Martino S, Wang M, Jones VE, Saphner TJ, et al. Prognostic value of tumor-infiltrating lymphocytes in triple-negative breast cancers from two phase III randomized adjuvant breast cancer trials: ECOG 2197 and ECOG 1199. J Clin Oncol. 2014;32(27):2959-66.

5. Denkert C, von Minckwitz G, Brase JC, Sinn BV, Gade S, Kronenwett R, Pfitzner BM, Salat C, Loi S, Schmitt WD, et al. Tumor-infiltrating lymphocytes and response to neoadjuvant chemotherapy with or without carboplatin in human epidermal growth factor receptor 2-positive and triple-negative primary breast cancers. J Clin Oncol. 2015;33(9):983-91.

6. Ohtani H, Mori-Shiraishi K, Nakajima M, Ueki H. Defining lymphocytepredominant breast cancer by the proportion of lymphocyte-rich stroma and its significance in routine histopathological diagnosis. Pathol Int. 2015;65(12):644-51.

7. Stanton SE, Adams S, Disis ML. Variation in the incidence and magnitude of tumor-infiltrating lymphocytes in breast cancer subtypes: a systematic review. JAMA Oncol. 2016;2(10):1354-60.

8. Loi S, Dushyanthen S, Beavis PA, Salgado R, Denkert C, Savas P, Combs S, Rimm DL, Giltnane JM, Estrada MV, et al. RAS/MAPK activation is associated with reduced tumor-infiltrating lymphocytes in triple-negative breast cancer: therapeutic cooperation between MEK and PD-1/PD-L1 immune checkpoint inhibitors. Clin Cancer Res. 2016:22 (6):1499-509.

9. Quigley D, Silwal-Pandit L, Dannenfelser R, Langerød A, Vollan HK, Vaske C, Siegel JU, Troyanskaya O, Chin SF, Caldas C, et al. Lymphocyte invasion in IC10/basal-like breast tumors is associated with wild-type TP53. Mol Cancer Res. 2015;13(3):493-501.

10. Ambrosone CB, Kropp S, Yang J, Yao S, Shields PG, Chang-Claude J. Cigarette smoking, $\mathrm{N}$-acetyltransferase 2 genotypes, and breast cancer risk: pooled analysis and meta-analysis. Cancer Epidemiol Biomarkers Prev. 2008;17(1):15-26.

11. Hecht SS. Tobacco smoke carcinogens and breast cancer. Environ Mol Mutagen. 2002;39(2-3):119-26.

12. Hanahan D, Weinberg RA. Hallmarks of cancer: the next generation. Cell. 2011;144(5):646-74.

13. Hanahan D, Coussens LM. Accessories to the crime: functions of cells recruited to the tumor microenvironment. Cancer Cell. 2012;21(3):309-22.

14. Schalper KA, Brown J, Carvajal-Hausdorf D, McLaughlin J, Velcheti V, Syrigos KN, Herbst RS, Rimm DL. Objective measurement and clinical significance of TILs in non-small cell lung cancer. J Natl Cancer Inst. 2015;107(3):dju435.

15. Mauri D, Pavlidis N, loannidis JP. Neoadjuvant versus adjuvant systemic treatment in breast cancer: a meta-analysis. J Natl Cancer Inst. 2005;97(3):188-94.

16. Mieog JS, van der Hage JA, van de Velde CJ. Preoperative chemotherapy for women with operable breast cancer. Cochrane Database Syst Rev. 2007:2:CD005002

17. Kawajiri H, Takashima T, Onoda N, Kashiwagi S, Noda S, Ishikawa T, Wakasa K, Hirakawa K. Efficacy and feasibility of neoadjuvant chemotherapy with
FEC 100 followed by weekly paclitaxel for operable breast cancer. Oncol Lett. 2012;4(4):612-6.

18. Eisenhauer EA, Therasse P, Bogaerts J, Schwartz LH, Sargent D, Ford R, Dancey J, Arbuck S, Gwyther S, Mooney M, et al. New response evaluation criteria in solid tumors: revised RECIST guideline (version 1.1). Eur J Cancer. 2009;45(2):228-47.

19. Kashiwagi S, Onoda N, Asano Y, Kurata K, Morisaki T, Noda S, Kawajiri H, Takashima T, Hirakawa K. Partial mastectomy using manual blunt dissection (MBD) in early breast cancer. BMC Surg. 2015;15:117.

20. Wolmark N, Wang J, Mamounas E, Bryant J, Fisher B. Preoperative chemotherapy in patients with operable breast cancer: nine-year results from National Surgical Adjuvant Breast and Bowel Project B-18. J Natl Cancer Inst Monogr. 2001:30:96-102.

21. Salgado R, Denkert C, Demaria S, Sirtaine N, Klauschen F, Pruneri G, Wienert S, Van den Eynden G, Baehner FL, Penault-Llorca F, et al. The evaluation of tumor-infiltrating lymphocytes (TILs) in breast cancer: recommendations by an International TILs Working Group 2014. Ann Oncol. 2015;26(2):259-71.

22. Kashiwagi S, Tsujio G, Asano Y, Goto W, Takada K, Takahashi K, Morisaki T, Fujita H, Takashima T, Tomita S, et al. Study on the progression types of cancer in patients with breast cancer undergoing eribulin chemotherapy and tumor microenvironment. J Transl Med. 2018;16(1):54.

23. Kashiwagi S, Asano Y, Goto W, Takada K, Takahashi K, Noda S, Takashima T, Onoda N, Tomita S, Ohsawa M, et al. Use of tumor-infiltrating lymphocytes (TILs) to predict the treatment response to eribulin chemotherapy in breast cancer. PLOS ONE. 2017;12(2):e0170634.

24. McShane LM, Altman DG, Sauerbrei W, Taube SE, Gion M, Clark GM Statistics subcommittee of the NCIEWGoCD: reporting recommendations for tumor marker prognostic studies. J Clin Oncol. 2005;23(36):9067-72.

25. Dossus L, Boutron-Ruault MC, Kaaks R, Gram IT, Vilier A, Fervers B, Manjer J, Tjonneland A, Olsen A, Overvad K, et al. Active and passive cigarette smoking and breast cancer risk: results from the EPIC cohort. Int J Cancer. 2014;134(8):1871-88.

26. Kawai M, Malone KE, Tang MT, Li Cl. Active smoking and the risk of estrogen receptor-positive and triple-negative breast cancer among women ages 20 to 44 years. Cancer. 2014;120(7):1026-34.

27. Park SY, Palmer JR, Rosenberg L, Haiman CA, Bandera EV, Bethea TN, Troester MA, Viscidi E, Kolonel LN, Olshan AF, et al. A case-control analysis of smoking and breast cancer in African American women: findings from the AMBER Consortium. Carcinogenesis. 2016;37(6):607-15.

28. Morabia A, Bernstein M, Ruiz J, Heritier S, Diebold Berger S, Borisch B. Relation of smoking to breast cancer by estrogen receptor status. Int J Cancer. 1998;75(3):339-42.

29. Manjer J, Malina J, Berglund G, Bondeson L, Garne JP, Janzon L. Smoking associated with hormone receptor negative breast cancer. Int J Cancer. 2001:91(4):580-4

30. Nishino Y, Minami Y, Kawai M, Fukamachi K, Sato I, Ohuchi N, Kakugawa Y. Cigarette smoking and breast cancer risk in relation to joint estrogen and progesterone receptor status: a case-control study in Japan. Springerplus. 2014;3:65

31. Cooper JA, Rohan TE, Cant EL, Horsfall DJ, Tilley WD. Risk factors for breast cancer by oestrogen receptor status: a population-based case-control study. Br J Cancer. 1989:59(1):119-25.

32. Nishioka T, Kim HS, Luo LY, Huang Y, Guo J, Chen CY. Sensitization of epithelial growth factor receptors by nicotine exposure to promote breast cancer cell growth. Breast Cancer Res. 2011;13(6):R113.

33. Melendez-Colon VJ, Luch A, Seidel A, Baird WM. Cancer initiation by polycyclic aromatic hydrocarbons results from formation of stable DNA adducts rather than apurinic sites. Carcinogenesis. 1999;20(10):1885-91.

34. Forteza RM, Casalino-Matsuda SM, Falcon NS, Valencia Gattas M, Monzon ME. Hyaluronan and layilin mediate loss of airway epithelial barrier function induced by cigarette smoke by decreasing E-cadherin. J Biol Chem. 2012;287(50):42288-98.

35. Kinoshita T, Muramatsu R, Fujita T, Nagumo H, Sakurai T, Noji S, Takahata E, Yaguchi T, Tsukamoto N, Kudo-Saito C, et al. Prognostic value of tumorinfiltrating lymphocytes differs depending on histological type and smoking habit in completely resected non-small-cell lung cancer. Ann Oncol. 2016:27(11):2117-23.

36. Donnem T, Hald SM, Paulsen EE, Richardsen E, Al-Saad S, Kilvaer TK, Brustugun OT, Helland A, Lund-Iversen M, Poehl M, et al. Stromal CD8 + T-cell 
density-A promising supplement to TNM staging in non-small cell lung cancer. Clin Cancer Res. 2015;21(11):2635-43.

37. Asano Y, Kashiwagi S, Goto W, Kurata K, Noda S, Takashima T, Onoda N, Tanaka S, Ohsawa M, Hirakawa K. Tumor-infiltrating CD8 to FOXP3 lymphocyte ratio in predicting treatment responses to neoadjuvant chemotherapy of aggressive breast cancer. Br J Surg. 2016;103(7):845-54.

38. Saquib N, Stefanick ML, Natarajan L, Pierce JP. Mortality risk in former smokers with breast cancer: pack-years vs. smoking status. Int J Cancer. 2013;133(10):2493-7.
39. Pierce JP, Patterson RE, Senger CM, Flatt SW, Caan BJ, Natarajan L, Nechuta SJ, Poole EM, Shu XO, Chen WY. Lifetime cigarette smoking and breast cancer prognosis in the after breast cancer pooling project. J Natl Cancer Inst. 2014;106(1):djt359.
Ready to submit your research? Choose BMC and benefit from:

- fast, convenient online submission

- thorough peer review by experienced researchers in your field

- rapid publication on acceptance

- support for research data, including large and complex data types

- gold Open Access which fosters wider collaboration and increased citations

- maximum visibility for your research: over $100 \mathrm{M}$ website views per year

At BMC, research is always in progress.

Learn more biomedcentral.com/submissions 